\title{
Morphological and mineralogical characterization of speleothems from the Chimalacatepec lava tube system, Central Mexico
}

\author{
Rafael López-Martínez ${ }^{1 *}$, Ricardo Barragán ${ }^{1}$, Hugo Beraldi-Campesi ${ }^{1}$, Tomáš Lánczos ${ }^{2}$, \\ Juan R. Vidal-Romaní3 ${ }^{3}$, Roman Aubrecht ${ }^{2,4}$, Juan P. Bernal Uruchurtu ${ }^{5}$, \\ Teresa Pi Puig, and Ramón Espinasa-Pereña ${ }^{6}$ \\ ${ }^{1}$ Institute of Geology, Universidad Nacional Autónoma de México, Ciudad Universitaria Campus, Coyoacán, C.P. 04510, México City, México \\ ${ }^{2}$ Department of Geochemistry, Faculty of Natural Sciences, Comenius University, Mlynská dolina Ilkovičova 6, SK-842 15 Bratislava, Slovakia \\ ${ }^{3}$ University Geology Institute, Elviña Campus. ESCI-3 Building. 15071 Coruña, Spain \\ ${ }^{4}$ Geophysical Institute, Slovak Academy of Sciences, Dúbravská cesta 9, SK-845 28 Bratislava, Slovakia \\ ${ }^{5}$ Geosciences Center, Universidad Nacional Autónoma de México. Juriquilla Boulevard 3000, Querétaro, C.P. 76230, México \\ ${ }^{6}$ Centro Nacional de Prevención de Desastres (“National Disaster Prevention Center"), Av. Delfin Madrigal No. 665, Coyoacán, C.P. 04360, México City, México
}

\begin{abstract}
Siliceous, opal-A speleothems of the Chimalacatepec lava tube system in central Mexico are characterized here for the first time. Morphologically, they can be classified into cylindrical and planar, and display a wide array of shapes, inner textures, and locations within the lava tube. All speleothems analyzed here are composed of opal-A, and their pores are filled with calcite and monohydrocalcite. Microscopic examination reveals a variety of microbial-looking, silicified filaments and cell casts embedded within the micro lamination of the structures. The abundance of biofilms in the Chimalacatepec lava tube may share similarities with other volcanic caves elsewhere. The direct presence of such bimorphs in the microstructure of the speleothems suggests the biological mediation of these structures. Potential mechanisms include nucleation and sorption of silica on extracellular polymeric substances in the biofilms that, along with the $\mathrm{SiO}_{2}$ saturation in the water film and evaporative effects, result in the formation of a speleothem. That said, the presence of microbes in these and other cave systems, or their inevitable interactions with the mineral phase of the speleothems, should not be surprising. In view of this, these structures can be most accurately described as biospeleothems. This study contributes to our understanding of the diversity of such structures in these types of cave systems and our ability to recognize the presence of microbes in these.
\end{abstract}

\footnotetext{
Keywords: $\quad$ lava tubes, siliceous speleothems, Chichinautzin, biospeleothems

Received 19 May 2015; Revised 22 February 2016; Accepted 22 February 2016

Citation: López-Martínez R., Barragán R., Beraldi-Campesi H., Lánczos T., Vidal-Romaní J.R., Aubrecht R., Bernal Uruchurtu J.P., Pi Puig T. and Espinasa-Pereña R., 2016. Morphological and mineralogical characterization of speleothems from the Chimalacatepec lava tube system, Central Mexico. International Journal of Speleology, 45 (2), 111-122. Tampa, FL (USA) ISSN 0392-6672 http://dx.doi.org/10.5038/1827-806X.45.2.1927
}

\section{INTRODUCTION}

Developing downhill from active volcanoes generally along the fastest flow of the lava extrusion -lava tubes retain the architecture of empty tube systems, which normally consists of a main tube with distributary tubes and other cavities (Greeley \& Hyde, 1972). During the first stages of lava tube formation, high-pressure heated fluids extruded from the tube walls cool down to form solid-rock lava formations throughout the inner walls (e.g., Allred \& Allred, 1998). Speleothems, which are also common on cave walls, develop differently, through the precipitation of secondary minerals. In the case of volcanic caves, these minerals are mainly amorphous silicates (opaline silica), although siliceous speleothems also develop in other type of caves, including doleritic (Sallstedt et al., 2014), granitic, and quartzitic caves (e.g., Urbani, 1976; Webb \& Finlayson, 1984; Wray, 1999; Léveillé et al., 2000; Willems et al., 2002; Forti et al., 2003; Forti, 2005; Aubrecht et al., 2008; Woo et al., 2008; Miller et al., 2012, 2014; Vidal-Romaní et al., 2010, 2015). Evidently, speleothem composition depends on the composition of the rocks in which caves develop.

Though the literature has made increasing emphasis on the presence of microbes in all cave types and it appears likely that these play an important role in speleothem development and preservation (Léveillé \& Datta, 2010; Northup et al., 2011 and references 
therein), the potential role of microbes in the morphological and compositional development of such structures (through the preferential accumulation of metals within a homogeneous mineral matrix) has only recently been considered (Allred \& Allred, 1998; Kempe, 2011), following the realization that microbes are ubiquitous in cave environments and can be responsible for much of the authigenic mineral formation/precipitation found in lava caves (Northup et al., 2011). When the deposition and morphological expression of speleothems are microbially mediated, the latter are known as biospeleothems (Aubrecht et al., 2008). A variety of such biospeleothems are known through the study of lava tubes and volcanic caves (Halliday, 1994; Leveille et al., 2000; Forti et al., 2003; Woo et al., 2008; Northup et al., 2011; DazaBrunet \& Bustillo-Revuelta, 2014; Miller et al., 2014).

The role microbes play in the development of speleothems is but one example of the broad range of microbe-mineral interactions that take place in underground environments, only recently recognized as sources of information for a broad variety of disciplines, including metalogeny and mineralogical exploration (e.g., Onac \& Forti, 2011), paleontology (Rasmussen et al., 2009), and astrobiology (Boston et al., 2001). As an example, speleothems formed within lava tubes reported in the literature from different localities, are potential repositories of paleoclimatic data. Recorded in their mineral structure and geochemistry, this data provides an alternative to that offered by carbonate speleothems (Lundberg et al., 2010). Thus, if paleoenvironmental reconstructions are to be made on the basis of these speleothems, prior understanding of the processes associated with their formation is required.

Here, we describe siliceous speleothems found in different areas of the inner tube and walls of lava tubes in central Mexico, and suggest that these developed through mineral precipitation in close association with microbial biofilms, caused by water flow and humidity on the ceiling and walls of the lava tubes. We propose that similar structures in lava caves around the world should be identified as biospeleothems.

\section{METHODS}

\section{Sampling site}

The Chimalacatepec lava tube system (EspinasaPereña, 2006) runs down the south slope of the Suchiooc Volcano, one the 200 basaltic-andesitic (calc-alkaline) cones that formed in the Holocene, less than 5000 years BP (Siebe et al., 2004) in the Chichinautzin volcanic field, near the town of San Juan Tlacotenco in central Mexico (Fig. 1). A total of $2.8 \mathrm{~km}$ of this lava tube system was mapped by Espinasa-Pereña (2006) and described as a master, canyon-shaped tube (tall and narrow; Fig. 2A) divided into 2 to 4 superposed cylindrical tubes (Fig. 2B), most with collapsed walls and top entrances (Figs. 1, 2C). Rugged wall sand lava formations, such as branched forms (Fig. 2D), primary cavities, wrinkles, and pinnacles are found throughout the system. Many tube systems in the Chichinautzin field remain unmapped.

\section{Sampling and analysis}

Siliceous speleothems were sampled along the Chimalacatepec system using small chisels and hammers. Small (representative) samples were collected to avoid cave deterioration. Water drips were collected from rock infiltrations using a syringe. $\mathrm{pH}$ and temperature measurements were made on site and samples sent out to the water analysis facility at the Geophysics Institute of the Universidad Nacional Autónoma de México (UNAM) for analysis of major and minor elements. Water samples were transported in dark bottles in ice and refrigerated at $4{ }^{\circ} \mathrm{C}$ in the laboratory for further analysis.

For mineralogy tests, samples were ground to $<75 \mu \mathrm{m}$ using an agate pestle and mortar and mounted in aluminum holders for X-ray powder diffraction (XRD) analysis. Measurements were made using a Shimadzu XRD-6000 diffractometer operating with an accelerating voltage of $40 \mathrm{kV}$ and a filament current of $30 \mathrm{~mA}$, using CuKa radiation and a graphite monochromator. All samples were measured over a $2 \theta$ angle range of $2-70^{\circ}$ at a speed of $1^{\circ} 2 \theta / \mathrm{min}$.

Morphological (see Vidal-Romaní et al., 2010, 2015) and genetic criteria (Hill \& Forti, 1995) were used for speleothem classification. Speleothem samples were axially and transversally cut and observed on a petrographic microscope with transmitted and polarized light. Representative thin-sections were stained with Alizarine Red for carbonate identification. Small fragments of speleothems were fresh fractured and etched with $3 \%$ hydrofluoric acid to expose structures within the speleothem microfabric, then sputtered coated with a gold film and observed on a JEOL 6300 Scanning Electron Microscope (Geology Institute, UNAM) at high vacuum in a range of 5-15 kV, equipped with a Bruker XFlash 4010 Electron Dispersive X-Ray detector.

\section{RESULTS}

\section{Morphological characterization of the speleothems}

All Chimalacatepec speleothems were composed of amorphous opal-A and separated by morphology into cylindrical and planar speleothems (see criteria for terminology in Vidal-Romaní et al., 2010, 2015).

\section{Cylindrical speleothems}

Cylindrical speleothems occurred in places with vertical to near-vertical water infiltration (flowing and non-flowing water films, usually with constant dripping) and exhibited a prominent positive relief. These were sub-divided based on morphology into:

- Opal-A straw stalactites (Fig. 3A). Thin and tubular structures hanging upside down and measuring 2 to $10 \mathrm{~cm}$ in length and 5 to $7 \mathrm{~mm}$ in diameter. They are hollow with an open end, associated with dripping water, mainly along fractures (Fig. 3B), and grow at the end of lava formations (Fig. 3C).

- Opal-A stalactites (Fig. 3D, E). These were associated with water dripping and exhibited conical or tooth-shaped structures. They are 

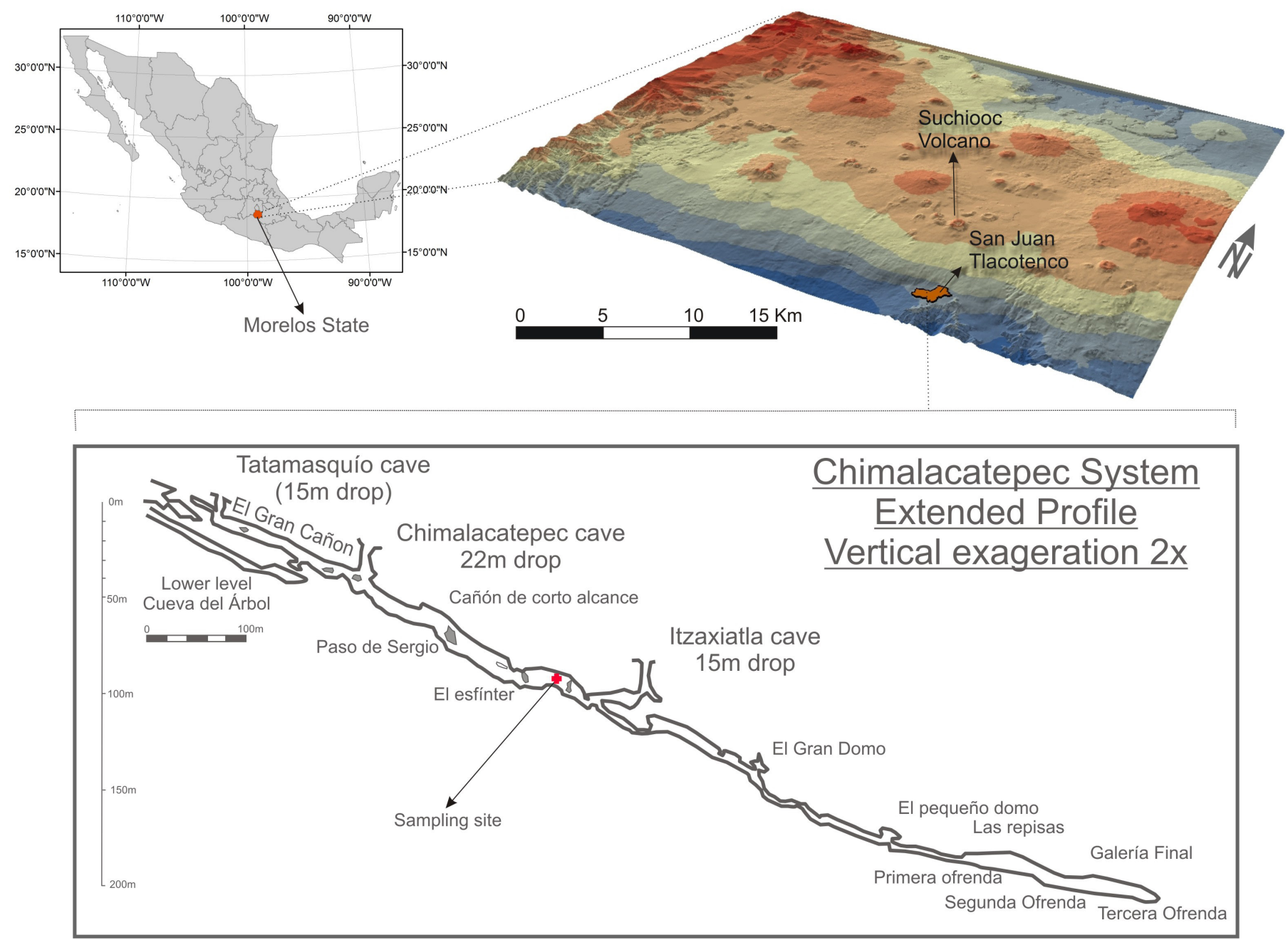

Fig. 1. Geographical location and underground structure of the studied Chimalacatepec lava tube.

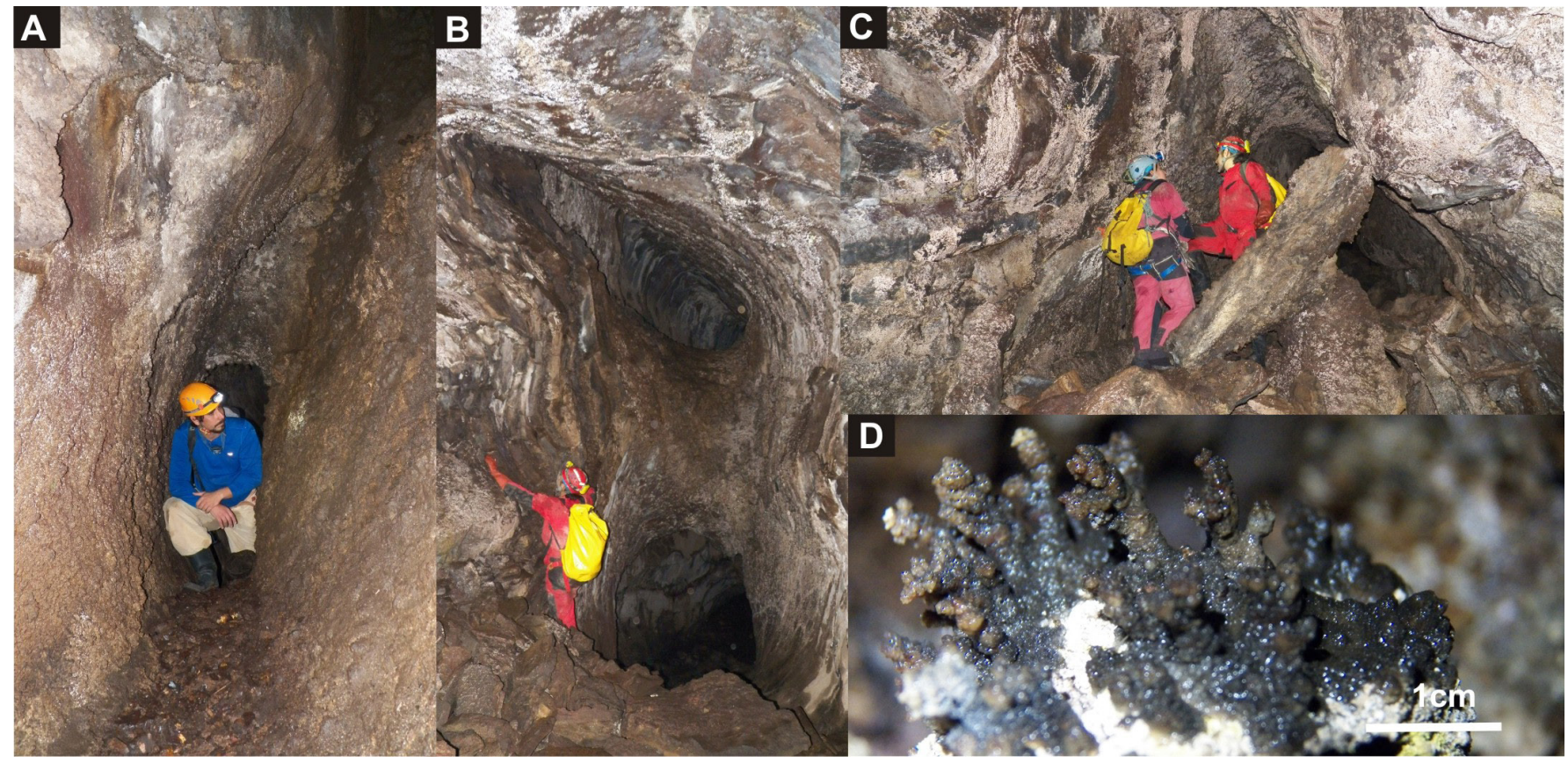

Fig. 2. Main characteristics of the Chimalacatepec lava tube. A) Canyon shape conduits; B) Superposed conduits; C) Wall and ceiling collapses; D) Lava formations resembling coralloids, and other frequent structures similar to stalactites and stalagmites.

less frequent than straw stalactites. Other speleothems resembling eccentric stalactites and anemolites (Fig. 3F, G) were common on the ceiling and on the walls, and were grouped here with stalactites due to their close relationship to water dripping processes.
- Opal-A branched forms (Fig. 3H). Bush-like structures displaying arborescent (multifurcated) growth and internal concentric microlamination. These speleothems display diverse forms and shapes. They may vary in size dramatically, from a few millimeters to $\sim 5 \mathrm{~cm}$, 
but have a cylindrical base and branching structures in common. The most common are arborescent structures that are found hanging on ceilings and protruding from walls. Kidney-shape morphologies are also frequent (Fig. 4A). Branched forms are usually covered by a thin water film and exposed to splashing water, but are not directly related to water dripping processes (Vidal Romaní et al., 2010, 2015). Branched forms are closely related to distinctive yellow and white biofilms, sometimes consisting of $1.5 \mathrm{~cm}$-thick mats of organic matter (Fig. 4B), similar to cave microbial mats described elsewhere (Northup et al., 2011; Hathaway et al., 2014). The relationship between these formations still remains unclear.

\section{Planar speleothems}

Formed from laminar water flows (Vidal Romaní et al., 2010, 2015), planar speleothems display a wavy relief and are divided by a grid of small depressions or microgours formed by water circulation (Vidal Romaní et al.,1998, 2010, 2015). Planar speleothems are divided into the following groups:

- Opal-A flowstones (Fig. 4C-E). These structures form a continuous cover on rock surfaces, and are only incipient in the Chimalacatepec lava tubes. They occur on the floor and walls, directly under the influence of dripping and flowing water (Fig. 4C), as well as in small ponds accumulated in depressions of the lava flow (Fig. 4D, E).

- Opal-A microgours (Fig. 4F). These appear in subvertical surfaces of 10 to 15 degrees (Fig. 4F) and are similar to those observed in granite caves as accumulations of grain mineral clasts with linear and sinuous development (Vidal-Romani et al.,2015), acting as temporary water traps.

- Opal-A terrestrial stromatolites (Fig. 5A-C). These structures occur on a near horizontal surface with no visible influence of either flowing or dripping water. This suggests that the necessary water might have been provided by condensation from the cave atmosphere (Vidal Romani et al., 2015) and probably water splash. Their relationship to actual biofilm (Fig. 4B), now under study, may explain their growth branched form.

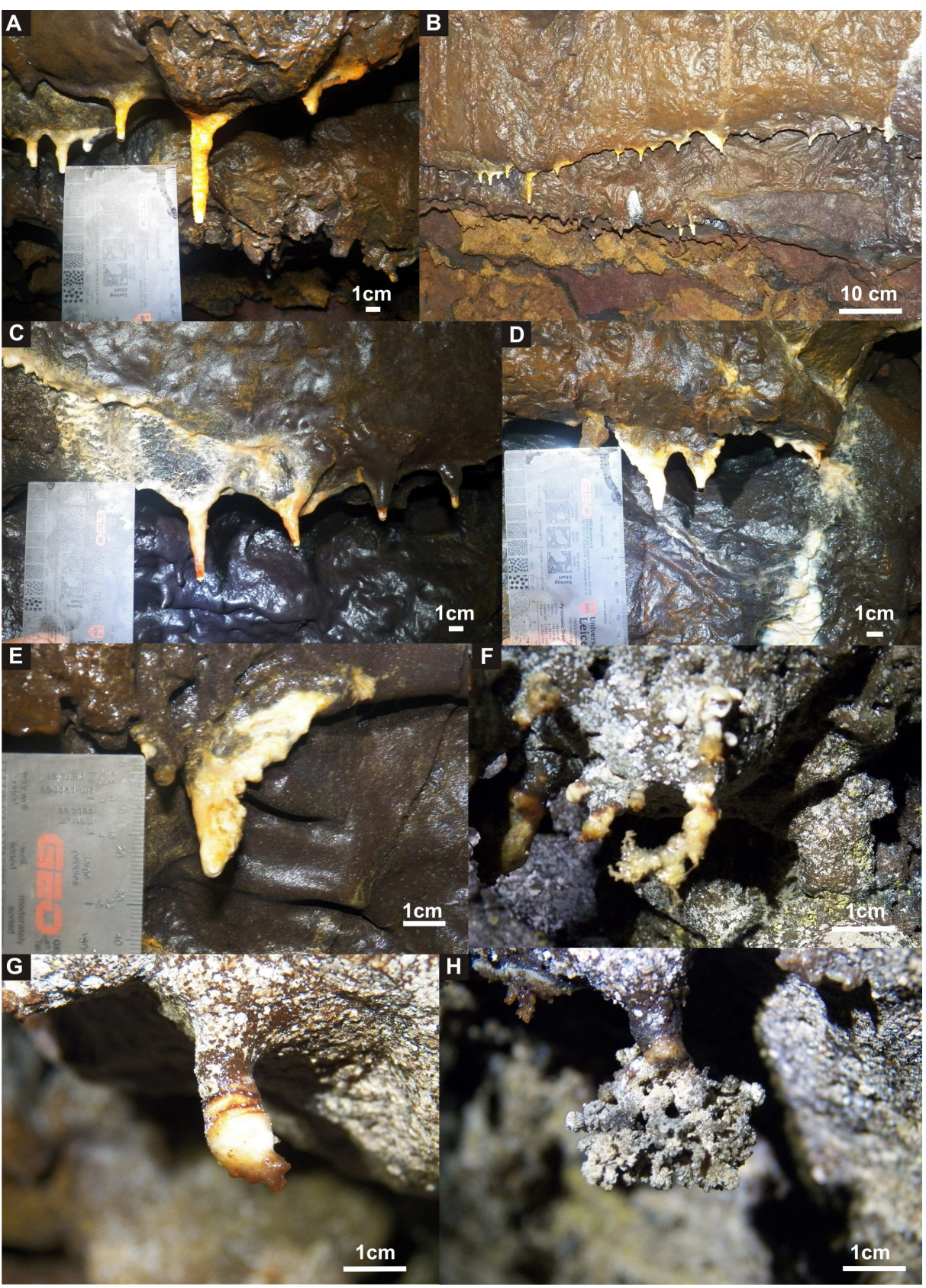

Fig. 3. Main morphologies of the cylindrical opal-A speleothems. A) Straw stalactites; B) Straw stalactites aligned along a fracture system. The fracture system provides enough water for with conical or tooth-shaped mineral developments; F) Siliceous speleothem resembling an eccentric stalactite; G) Siliceous speleothems displaying anemolite-like shapes; H) Opal-A

inside wet bacterial mats. These speleothems present two main morphologies: botryoidal and cookie-like shapes (Fig. 5A). Cross sections of cookie-like structures (Fig. 5B) display terrestrial stromatolitic lamination (Fig. 5C) at the base and top. The center is usually porous, and microstromatolitic growth $(<1 \mathrm{~cm}$ in diameter $)$ perches through the different laminar crusts, reaching the top of the structure to form small knobs (Fig. 5C).

\section{Speleothem fabrics and mineralogy}

The speleothems studied are composed mainly of opal-A and present porous spaces that have been infilled with carbonate cements through a secondary process. (Fig. 6). That said, the diversity of textures revealed by thin section analysis allowed for the separation of the two main morphologies 

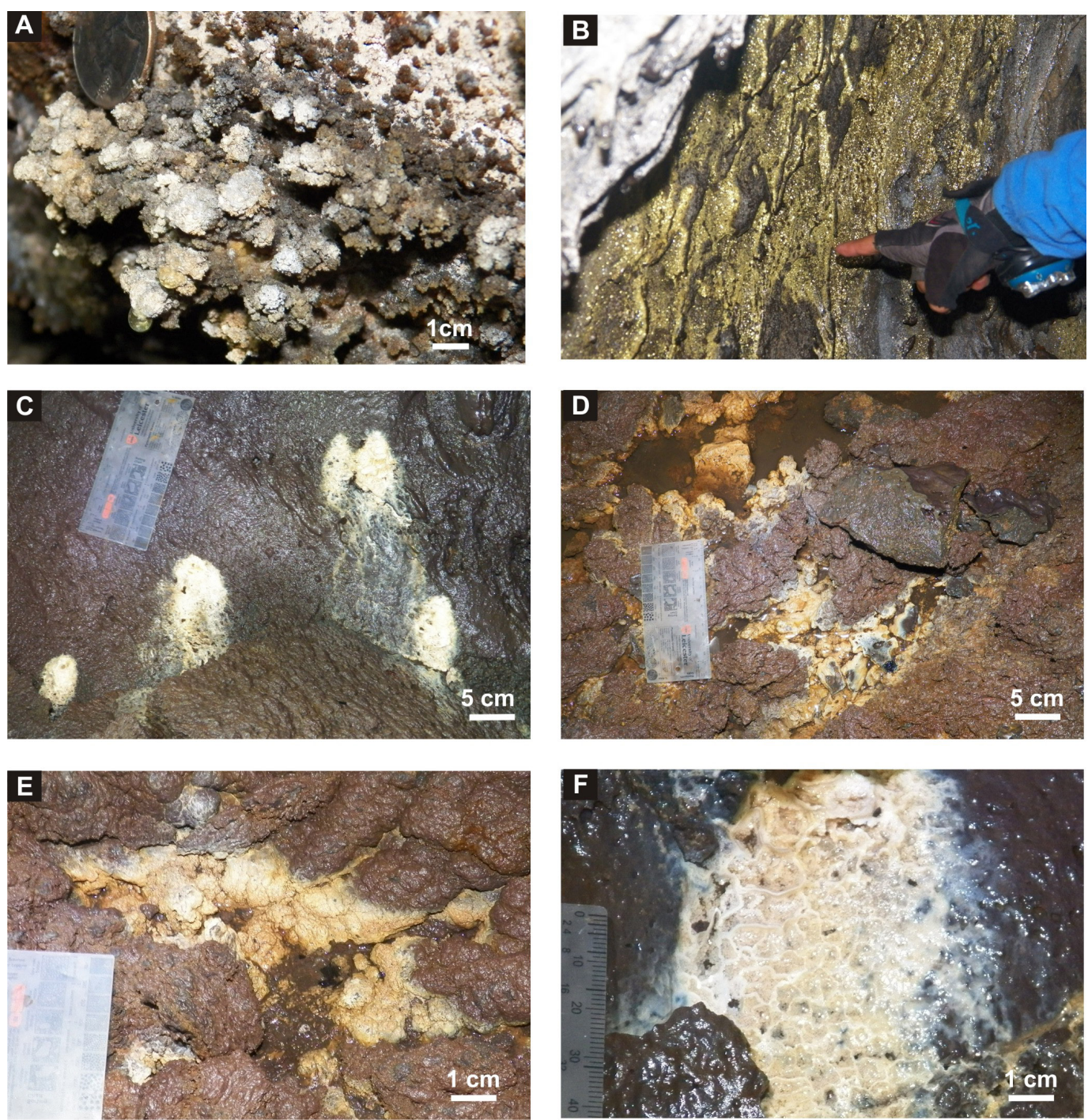

Fig. 4. Major morphologies of cylindrical and planar biospeleothems. A) Kidney-shaped speleothem on the lava tube wall; B) Yellow biofilms, sometimes $\mathrm{cm}$-thick mats of organic matter covering lava cave walls and containing spherical water drops at the surface, conferring a beautiful gold shine to the surfaces; C) Opal-A flowstones;

$D, E)$ Opal-A flowstones in small ponds formed in depressions of the lava flow; F) Opal-A microgour.

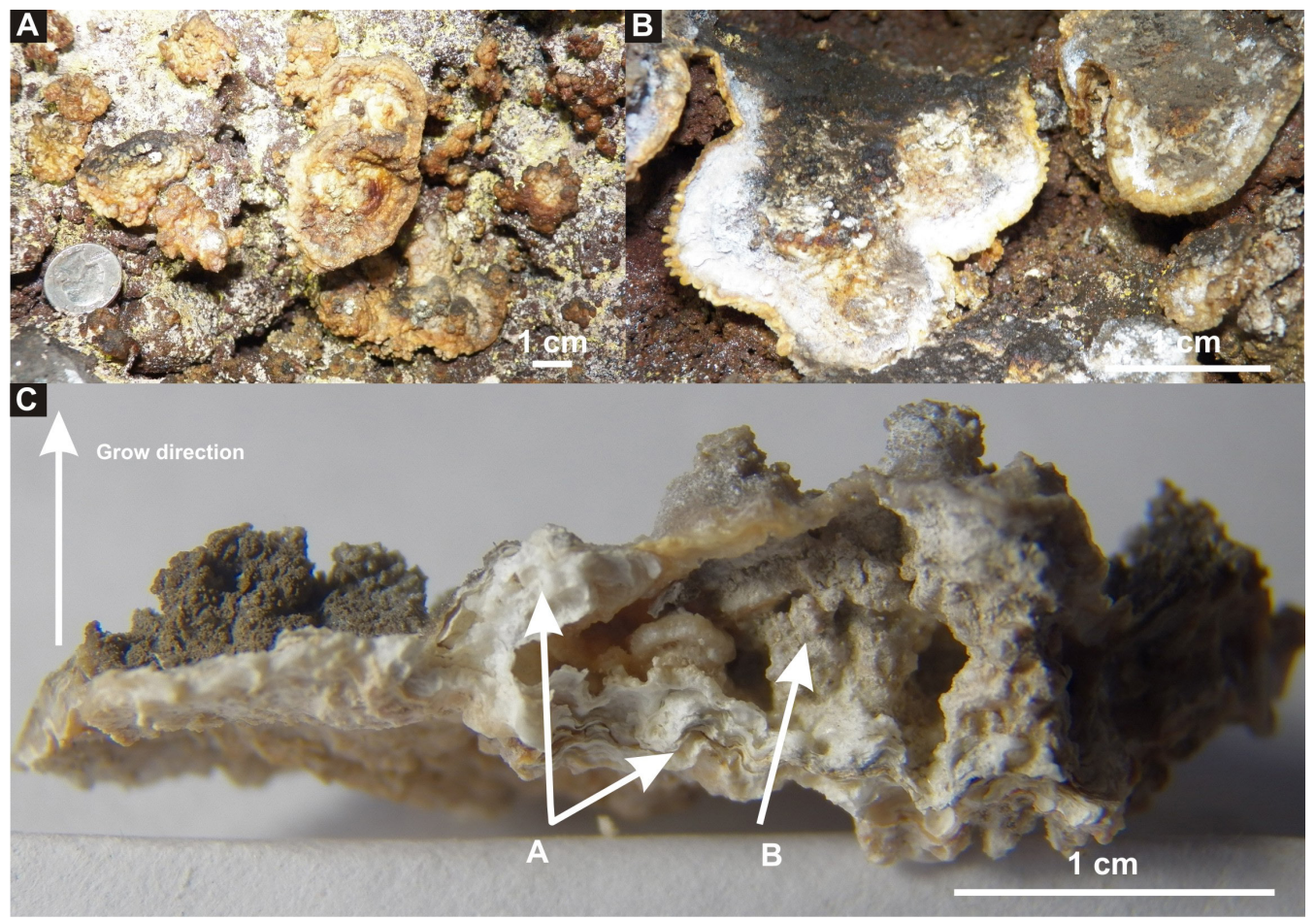

Fig. 5. Morphology and internal structure of terrestrial stromatolites. A) Two main morphologies, botryoidal and cookie-like shapes, coexist in a small area; B) Detail of the cookie-like shape exterior morphology with serrated margin; C) Internal structure of a cookielike stromatolitic grow. The 'A' arrow points to a fine wavy lamination and the 'B' arrow points to the micro-stromatolitic growth. 


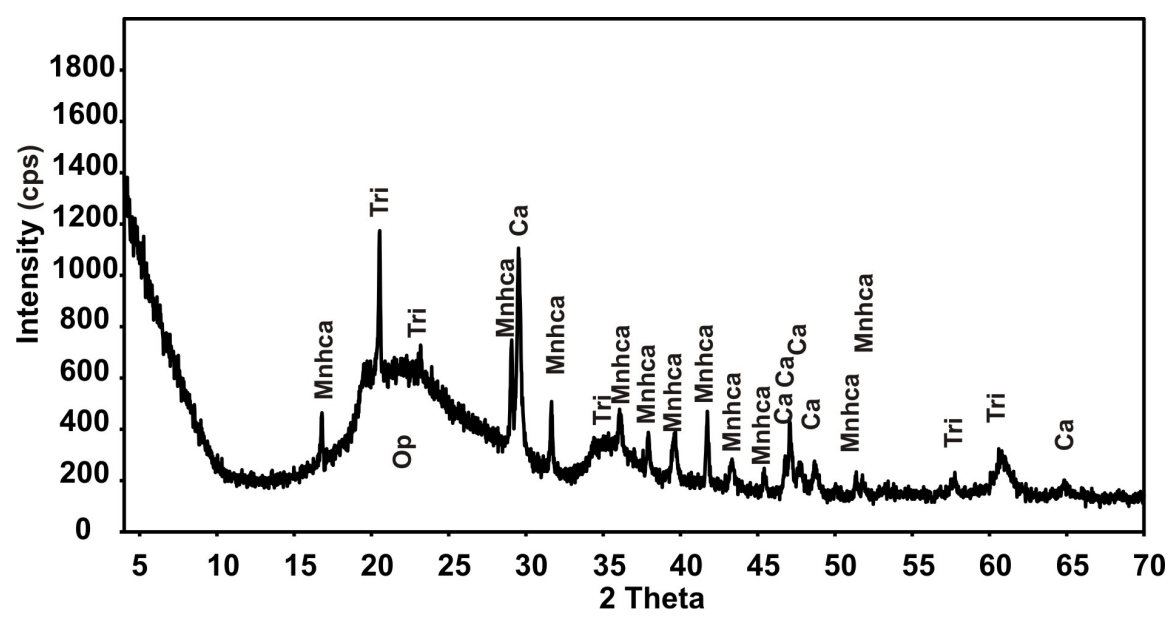

Fig. 6. XRD spectrum of the cylindrical speleothems. Mnhca: Monohydrocalcite, Tri: Tridimite, Ca: Calcite: Op: Opal-A. Full Width at Half Maximum $(\mathrm{FWHM})=7.7$

(branched forms and terrestrial stromatolites) and suggest a slightly different genetic process. The two morphologies were therefore studied separately.

\section{Branched structures}

Branched structures display micrometric lamination in cross section (Fig. 7). Petrographic analyses reveal different zones of mineral growth (Fig. 7A). From base to top, these are:

A) Solid opal-A clear to cloudy (Fig. 7A, A arrow). Varies from translucent to gray in color. The
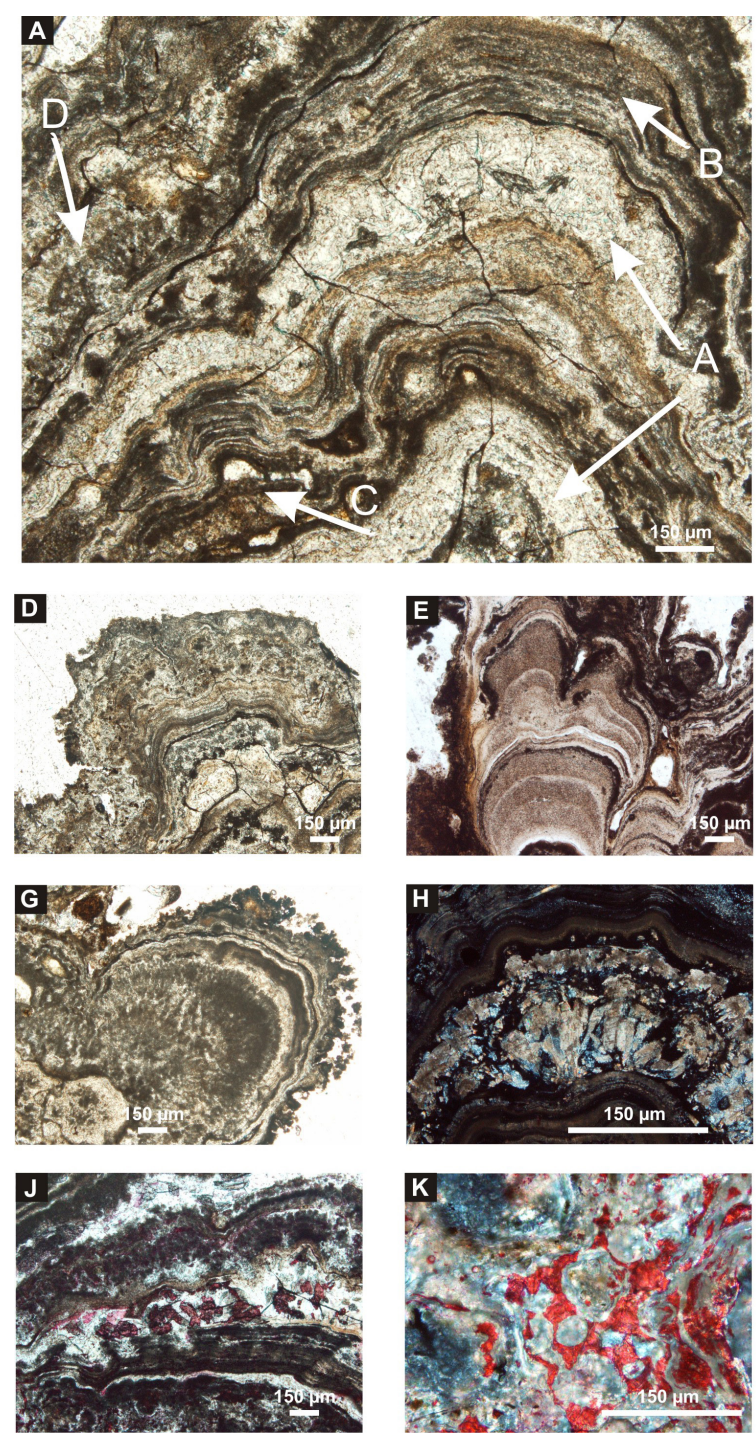
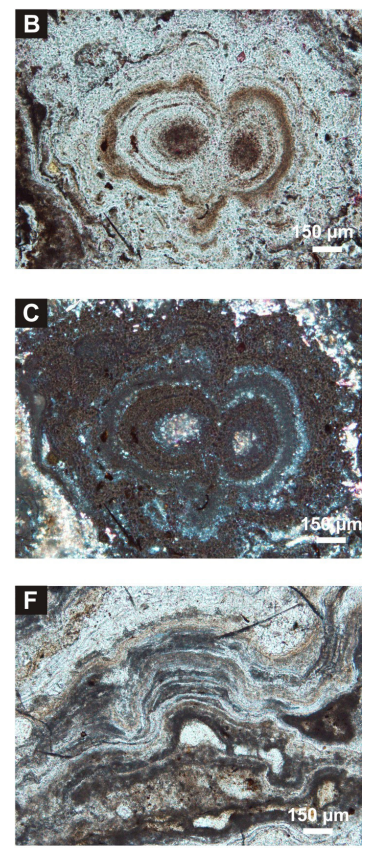

main area is non-laminated and non-porous, but micro-lamination or cryptic lamination is observed in small areas. Microbial ooids up to $750 \mu \mathrm{m}$ in size are also seen in some samples (Fig. 7B, C). The nuclei of microbial ooids are generally small particles of basalt derived from the cave rock.

B) Micro-laminated opal-A (Fig. 7A, B arrow). This area is characterized by thin lamination varying in color from translucent to brown (Fig. 7D, E). Lamination is mainly parallel to the lower base and follows the irregularities of the basal part. In some parts, these laminas conform domes with wavy lamination, typical of stromatolitic grow (Fig. 7E).

C) Porous-vesicle zone. Only present where parallel crusts sandwich the interspaces of columnar micro-stromatolites and is characterized by abundant pores that are sometimes interconnected (Fig. 7F).

D) Dendritic-arborescent zone. Composed of small, dark, peloid-like particles forming a dendriticarborescent pattern or lumps cemented by opal-A, obliterating primary porosity (Fig. 7G).

Some porous zones of the internal structure of the speleothems display a variety of calcite crystals in blade spar cement (Fig. 7H), fibrous growth (Fig. 7I), dogteeth shapes (Fig. 7J), meniscus and drusy habits (Fig. 7K), and euhedral crystals (Fig. 7L). Alizarin staining (i.e., Fig. 7I-L) reveals carbonate cements infilling porous spaces and coating internal voids.

\section{Terrestrial stromatolites}

Based on XRD analysis, the terrestrial stromatolites show even more amorphous mineral phases than branched forms (Fig. 8). Their mineralogical composition is similar to that of branched forms, except for the absence of monohydrocalcite. Part of the micro-stromatolitic growth (Fig. 9A, B) displays solid opal-A laminations with no obvious porosity, often with a clotted-brecciated texture (Fig. 9C). Small sub-spherical structures
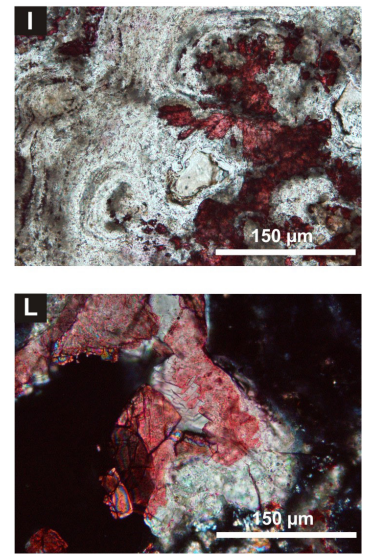

Fig. 7. Petrographic thin sections of the cylindrical speleothems. A) Differentiation into A, B, C, D zones (arrows) according to their petrographic fabrics; B, C) Microbial ooids in plane (B) and cross polarization (C). These microbial ooids correspond to the A zone; $D, E)$ Dense opal of the B zone; F) Porous-vesicle zone; G) Peloidal Zone. Dark microbial peloids are seen arranged in parallel lamination and in a dendritic pattern; H-L) Calcite crystal habits; H) Blade spar and fibrous calcite cement; I-L) Alizarin stained areas showing calcite in red; I, J) Dog tooth calcite cement; K) Meniscus and drusy calcite cement; L) Euhedral calcite crystals. All scale bars are $150 \mu \mathrm{m}$ in length. 


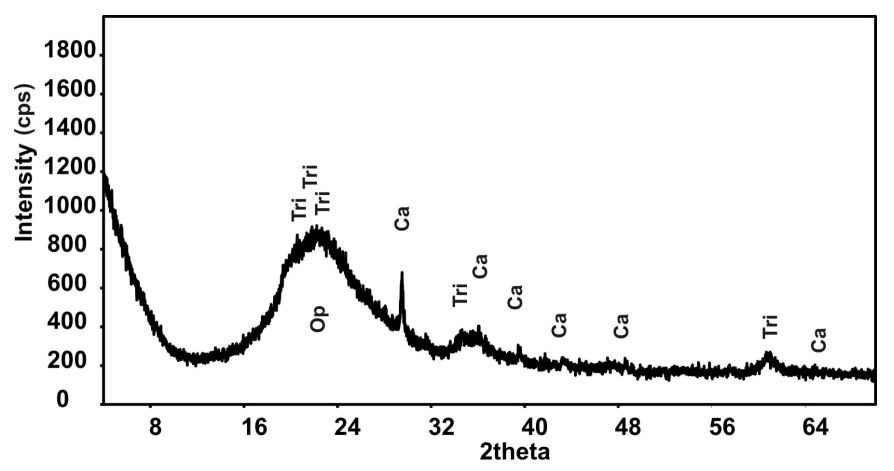

Fig. 8. X-ray diffractogram spectra of planar speleothems showing low crystallinity in minerals: Tri: Tridimite, Ca: Calcite: Op: Opal-A. Full Width at Half Maximum (FWHM) $=7.9$.

similar to those described by Aubrecht et al. (2008) as organic structures (Fig. 9D) are present within the lamination. Opal-A ooids (Fig. 9E, F) are scarce. Thincrust lamination alternates with zones having abundant peloids (Fig. 9G) arranged as thrombolitic (clotted) (Fig. 9G, A arrow) and dendrolitic fabrics (Fig. 9G,
B-arrow), and is very similar to those described for branched forms (D zone). Calcium carbonate appears to infill porous spaces in a way similar to that observed in branched forms (Fig. 9H, I).

\section{Scanning electron microscopy and hidrogeochemistry results}

SEM analyses reveal interesting aspects of the speleothem textures and composition (Fig. 10A-C). The porous zone exhibits a complex tridimensional structure of interconnected pores (Fig. 10D) typical of biofilm layers. The surfaces of branched forms display a lumpy texture or complex structures resulting from the growth of stromatolitic domes (Fig. 10E).

Branched forms exhibit a complex structure composed of abundant opal-A nanospheres (Fig. 10F-H) in a distinctive arrangement and with slight differences in chemical composition. Monohydrocalcite infills some pores. Electron Dispersive Spectroscopy (EDS) analyses of these arrangements are shown in Table 1.
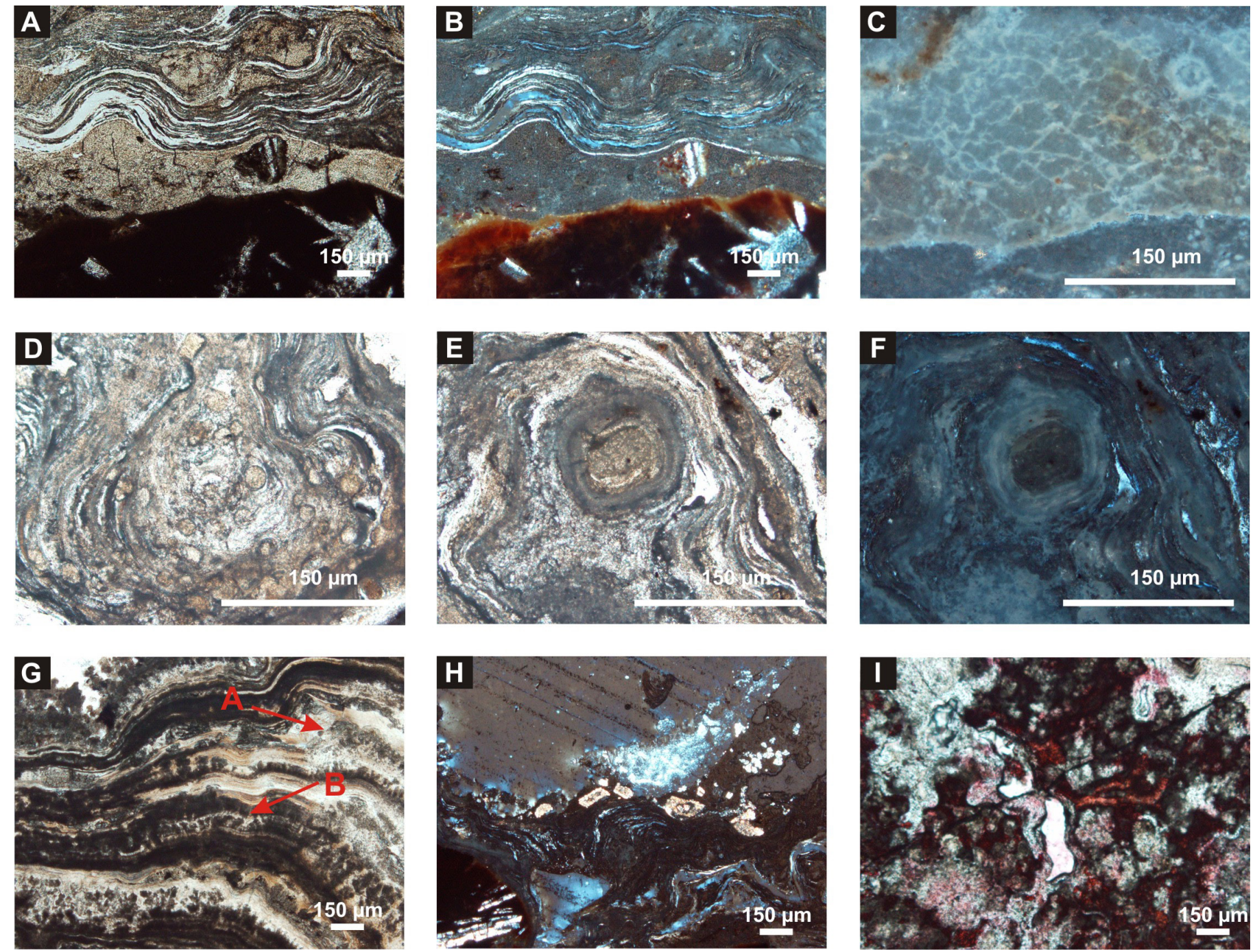

Fig. 9. Planar speleothems in thin sections. A, B) Microstromatolitic growth; C) Clotted-brecciate texture; D) Circular structures probably caused by biogenic activity; E, F) Siliceous microbial ooids under plane polarization (E) and cross polarization (F); G) Peloidal zone with thrombolitic (clotted) fabric (A arrow) and dendrolitic growth (B arrow); H) Calcite growth in porous zones; I) Alizarin staining showing porous calcite infilling. All scale bars are $150 \mu \mathrm{m}$ in length.

We can observe numerous microbial-like filaments encrusted in opal-A (Fig. 10I) in both branched forms and terrestrial stromatolites. These filaments appear as a microbial mat or biofilm that developed as stacked layers with very thin lamination
(Fig. 10J-L). Abundant silicified cell casts or parts of organisms up to $20 \mu \mathrm{m}$ in size are also present (Fig. 10M-O). Even when morphologies resemble organic structures it is very difficult to associate them to a specific organism. 

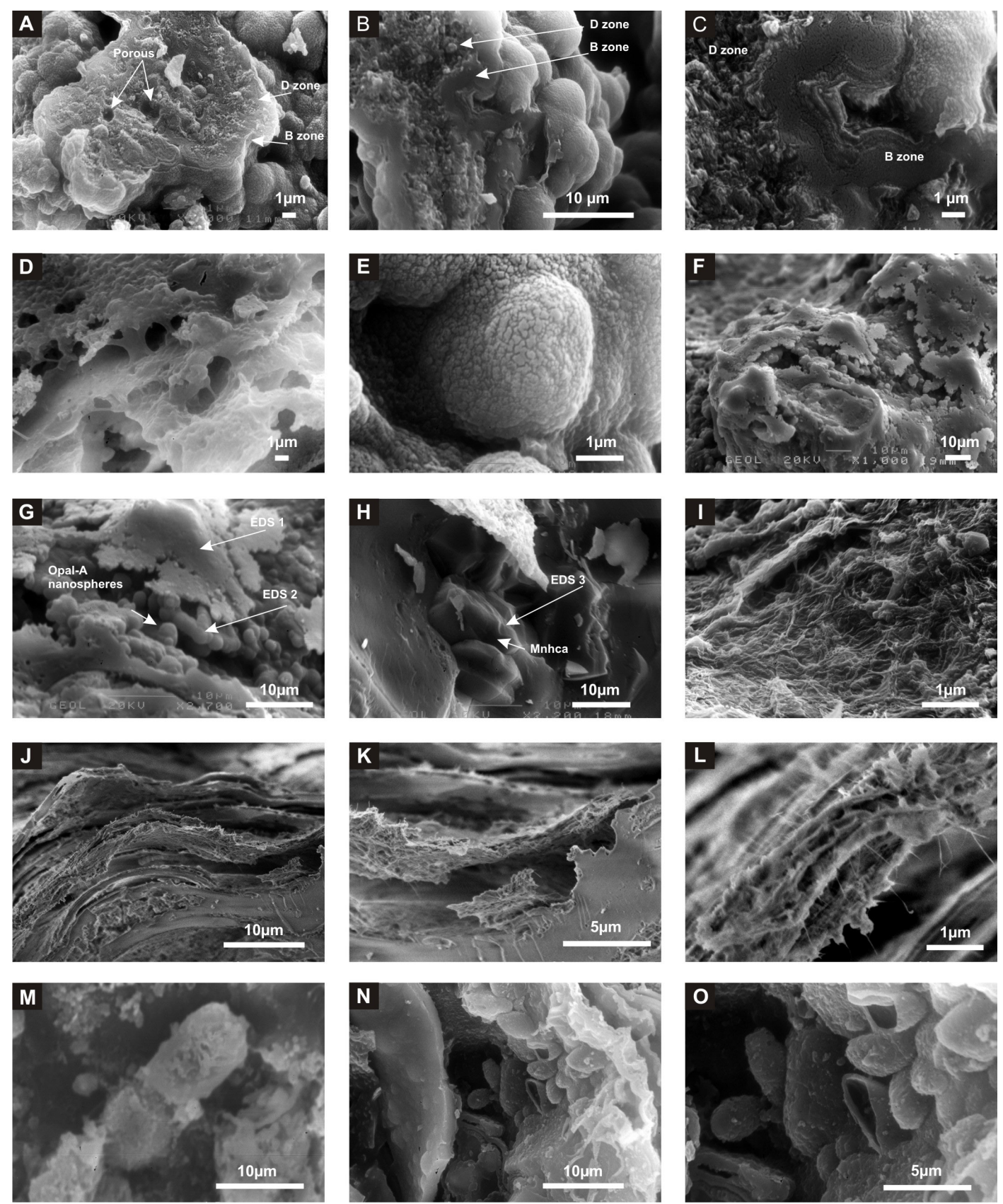

Fig. 10. Microscopic features of siliceous speleothems. A, B, C) Details of the zones described in the petrographic analysis. Arrows indicate the different zone distribution with the same nomenclature for those described in Fig. 7;

D) Porous zone formed by the biofilm EPS stretching out between layers of opal spheres; E) Structures in the surface of branching forms resembling lumpy texture or complex structures of stromatolitic grow; F, G) Two different growth stages of the speleothems. The Opal-A nanospheres with high porosity are covered with a less porous layer or biofilm. This succession can reflect a change between dry and humid periods. See text for explanation. Arrows indicate the positions for EDS analysis; H) Calcite and monohydrocalcite infilling porous zones. Mhnca: monohydrocalcite. Arrow shows the position of the EDS target; I) Numerous silicified filaments and EPS remains; J, K, L) Microbial biofilms; M) Cell cast; N) Group of silicified cell casts; O) Magnification of figure N.

Table 1. EDS results on speleothems. Location of analyzed points are shown in Fig. 10G, $\mathrm{H}$.

\begin{tabular}{|c|c|c|c|}
\hline $\begin{array}{c}\text { Compound } \\
\text { Formula }\end{array}$ & $\begin{array}{c}\text { Compound } \\
\text { Wt \%EDS 1 }\end{array}$ & $\begin{array}{c}\text { Compound Wt } \\
\text { \% EDS 2 }\end{array}$ & $\begin{array}{c}\text { Compound } \\
\text { Wt \% EDS 3 }\end{array}$ \\
\hline $\mathrm{SiO}_{2}$ & 55.29 & 66.7 & $\mathbf{4}$ \\
\hline $\mathrm{TiO}_{2}$ & 0.14 & 0.14 & 0.18 \\
\hline $\mathrm{Al}_{2} \mathrm{O}_{3}$ & 0.71 & 0.49 & 1.31 \\
\hline $\mathrm{MgO}$ & 2.06 & 1.23 & 1.02 \\
\hline $\mathrm{MnO}$ & 0.53 & 0 & 0 \\
\hline $\mathrm{CaO}$ & 16.09 & 0.64 & 37.66 \\
\hline $\mathrm{K}_{2} \mathrm{O}$ & 0.06 & 0 & 0 \\
\hline $\mathrm{Na}_{2} \mathrm{O}$ & 0 & 0.02 & 0.02 \\
\hline $\mathrm{Fe}_{2} \mathrm{O}_{3}$ & 0 & 0 & 0.39 \\
\hline $\mathrm{CO}_{2}$ & 25.12 & 30.77 & 55.44 \\
\hline
\end{tabular}

A chemical analysis of the water drip in the area speleothems were sampled (see Fig. 1 for location) reveals high concentrations of $\mathrm{SiO}_{2}$ and $\mathrm{Mg}^{2+}$ and low concentrations of other elements (Table 2).

Table 2. Chemical composition of water drips in the studied lava tube.

\begin{tabular}{|c|c|}
\hline Parameter & $\begin{array}{c}\text { Value, } \\
\text { concentration (mg. } \mathbf{1}^{-1} \text { ) }\end{array}$ \\
\hline $\mathrm{pH}$ & 6.71 \\
\hline $\mathrm{SiO}_{2}$ & 22.7 \\
\hline $\mathrm{Ca}^{2+}$ & 4.8 \\
\hline $\mathrm{Mg}^{2+}$ & 26.2 \\
\hline $\mathrm{Na}^{+}$ & 6 \\
\hline $\mathrm{K}^{+}$ & 2.4 \\
\hline
\end{tabular}




\section{DISCUSSION}

The internal structures of the Chimalacatepec speleothems present some similarities to those previously described from other non-carbonate caves (Léveillé et al., 2000; Aubrecht et al., 2008; Woo et al., 2008; Vidal-Romaní et al., 2010, 2015; Miller et al., 2012, 2014; Daza et al., 2014). Their genesis encompasses at least two major stages of development: the first stage is associated with the precipitation of opal-A, whereas the second involves the precipitation of monohydrocalcite and calcite. We are able to identify these two stages because the minerals are clearly separated (as seen in thin sections), with calcite appearing as secondary cement infilling pores and opal-A conforming the main sedimentary structures (Fig. 7H-L and Fig. 9H, I).

One possible explanation could be related with succession of wet-dry periods. Opal-A ooids (Fig. 7B, C; Fig. 9E, F) and brecciate texture records (Fig. 9C) are evidences suggesting variations in the volume in the biofilm by desiccation and rehydration. Though not considered in the present study, the record of ooids in this type of environment seems to be closely related to pedogenetic ooids described in calcic soils (Robin et al., 2015). For these structures to form, periods in which the increase of porosity allows the coating of small particles to form a three-dimensional layered structure are required. The brecciate textures can also be explained by periods in which the desiccation of mats allow the formation of cracks that are cemented and covered by opal-A during wet period.

During wet periods, the biofilm receives a constant supply of $\mathrm{SiO}_{2}$-saturated water that circulates throughout the fissure network system. This provides a stable physicochemical environment that prevents significant changes in the $\mathrm{pH}$ of the solution, favoring the precipitation of silica within the extracellular polymeric substances (EPS). In contrast, during the dry periods, the amount of percolating water is limited, which may facilitate the evaporation of the surficial water film (with subsequent saturation), increasing the biofilm porosity and allowing $\mathrm{pH}$ changes in microsites within the EPS caused by bacterial $\mathrm{CO}_{2}$ consumption.

The fact $\mathrm{Mg}^{2+}$ concentrations are considerably higher than those of $\mathrm{Ca}^{2+}(6: 1)$ in water chemistry (Table 2) is probably a consequence of the dissolution of mafic Mg-bearing minerals such as amphiboles, pyroxenes, and olivines, all typical for basalts.

We explain calcite precipitation as a direct relationship that exists between seasonal conditions (dry-wet periods) and biological action. In soils, the oxidation of organic matter and biological activity of plants and microorganisms favor the production of $\mathrm{CO}_{2}$ and $\mathrm{HCO}_{3}{ }^{-}$. Also soil allow the interaction of basalt minerals with organic acids increasing the velocity of dissolution of silica (Bennett et al., 1988; Bennett, 1991).

Once entering the cave, silica from $\mathrm{SiO}_{2}$-saturated solutions can precipitate due to super-saturation of thin water films aided by bacterial EPS. Orange et al. (2013) experimentally demonstrated that nonbiologically mediated silica precipitation produces a dense matrix, due to the continuous infilling of porous structures by silica, but in the presence of the cyanobacterium Synechococcus elongates, silica precipitated in the EPS to conform a disorganized and porous sinter. Sinters collected by Orange et al. (2013) present some similarities with the opal-A speleothems studied in the present work. The occurrence of different zones (A through D, see Fig. 7A) in studied opal-A speleothems can be correlated with the presence or abundance of different microorganisms (yet to be identified). Thus, the occurrence of Zone A (solid opal-A) can be largely justified by in organic precipitation of opal-A, whereas zones B, C, and D are very similar to those described by Orange et al. (2013). These are influenced by microorganisms such as chemolithotrophic bacteria within pores, whose $\mathrm{CO}_{2}$ consumption activity results in higher $\mathrm{pH}$, allowing for the precipitation of $\mathrm{CaCO}_{3}$.

As the source of the silicon and calcium found in the samples collected at the Chimalacatepec lava tube system is exclusively basaltic rock, we have proposed three main stages of development, based on the $\mathrm{SiO}_{2}-\mathrm{CaCO}_{3}$ relationship and microbial activity.

\section{First stage}

In the first stage, silica plays the main role. The release of silica from the rock is owed to rock alteration (Forti, 2005) caused by the weathering of silicate minerals within the basaltic lava, favored by interaction with organic acids (Bennett et al., 1988; Bennett, 1991). In both planar and cylindrical speleothems this deposition stage is correlated with dense opaline zones (Zone A in Fig. 5A). The initial deposition of opal-A could be due to inorganic precipitation of silica from thin water films in lava cave walls. The presence of ooids and brecciate textures in this stage suggests a change in cave environment from wet to dry and perhaps incipient microbial action.

\section{Second stage}

This stage is clearly mediated by biological processes. Terrestrial stromatolites display certain similarities to those described by Aubrecht et al. (2008) and VidalRomani et al. (2015), and reveal an important biogenic contribution to speleothem growth.

\section{Third stage}

The third phase is related to carbonate infilling of voids and pores. Forti (2005) has defined two conditions for the deposition of carbonates in lava caves. These are the rise of $\mathrm{pCO}_{2}$ in the solution entering in lava tubes, and the increase of calcium and/or magnesium concentration in water. The increase of $\mathrm{pCO}_{2}$ apparently follows the development of a thick soil layer above the lava field, which allows an intensive weathering of silicate minerals, providing cations for carbonate mineral precipitation inside the lava tube. This thick soil layer provides the medium for numerous microbial reactions (especially heterotrophy) that release considerable quantities of $\mathrm{CO}_{2}$. The Chimalacatepec lava tube system is currently covered by a thin soil horizon (30-40 cm) and oak trees found in humid environments, thus, a favorable medium that could support microbial activity. 
Precipitation of calcite from this low-saturated solution (see Table 2) can be explained by evaporation and the formation of thin saturated water films (Dreybrodt, 1980, 1981), as well as special microenvironments inside the porous rocks, in which the bacterial $\mathrm{CO}_{2}$ consumption increases the $\mathrm{pH}$, allowing calcium carbonate precipitation. The variety of textures observed in thin sections (Fig. 7H-L) suggests a complex calcite precipitation process with more than one process and more than one mineralization stage involved.

Owing to its instability with respect to anhydrous calcite (Rodríguez-Blanco et al., 2014), Monohydrocalcite is a rare mineral. The precipitation of this mineral in such micro-environments appears to be determined by high concentrations of magnesium in the solution (Leveillé et al., 2000; Neumann \& Epple, 2007; Munemoto \& Fukushi, 2008; Last et al., 2010; Kimura $\&$ Koga, 2011) aided by the evaporation of water in the interior of mats and surrounding areas or may be as the result of biochemical activity (Polyak et al., 1994; Onac et al., 2009). Unfortunately, our current data does not allow us to propose a robust mechanism to account for the presence of this mineral in lava tubes.

No chronological data for the studied opal-A speleothems is available, but it is worthwhile to note that X-ray diffraction reveals a very low-ordered opal-A for both branched forms and terrestrial stromatolites (Figs. 6 and 8). The Full Width at Half Maximum (FWHM), used as a mineralogical maturation index, yields values between 7.7 and 7.9 , indicative of a very immature opal-A (Herdianita et al., 2000; Lynne et al., 2008). The values of the FWHM and the absence of opal-CT or opal-C suggest that the studied samples have not undergone diagenetic processes, allowing us to assume that they are very young. We must note that U-Th dating of opaline minerals is usually hampered by the large concentration of detrital Th (Ludwig \& Paces, 2002).

\section{CONCLUSIONS}

The Chimalacatepec lava tube system displays a variety of opal-Aspeleothems that can be framed in two main groups: cylindrical and planar speleothems. They are composed mainly of opal-A and subordinate calcite and monohydrocalcite, precipitated in a second mineralization stage.

The presence of opal-A and calcite are clearly mediated by biological processes favoring both, the dissolution and precipitation of silica and the precipitation of calcite inside rock pores through the formation of special microenvironments. The speleothems display traces of organic features such as terrestrial stromatolite-like laminations with abundant cell casts embedded in opal-A. We therefore suggest these formations may be classified as biospeleothems.

\section{ACKNOWLEDGMENTS}

This research paper was funded by the UNAMDGAPA-PAPIIT IA103415, IN-108709 and IN-109912-
3 projects, as well as CONACyT-SEP 177510. We want to thank Margarita Caballero Miranda (Geophysics Institute, UNAM), Berenit Mendoza Garfias (Biology Institute, UNAM), Margarita Reyes Salas and Sonia Angeles García (Geology Institute, UNAM) for their technical support in SEM imaging and analysis processes, and Maria Aurora Armienta (Geophysics Institute, UNAM) for conducting the water analyses. Special thanks to Angeles Verde Ramirez and Ramses Miranda Gamboa from UNAM's Grupo Espeleológico Universitario ("University Speleology Group”, GEU) for their assistance in the sampling process, and to Adriana Espino del Castillo, for her useful comments and suggestions. The authors also wish to express their gratitude to Dr. Paolo Forti and to the three anonymous reviewers, whose comments on the first draft of this manuscript helped improve the quality of the work.

\section{REFERENCES}

Allred K. \& Allred C., 1998 - Tubular lava stalactites and other related segregations. Journal of Cave and Karst Studies, 59 (2): 130-140.

Aubrecht R., Brewer-Carias C.H., Šmída B., Audy M. \& Kováčik L., 2008 - Anatomy of biologically mediated opal speleothems in the world's largest sandstone cave Cueva Charles Brewer, Chimanta Plateau, Venezuela. Sedimentary Geology, 203: 181-195.

http://dx.doi.org/10.1016/j.sedgeo.2007.10.005

Bennett P., 1991 - Quartz dissolution in organic-rich aqueous solutions. Geochimica et Cosmochimica Acta, 55: 1781-1797.

http://dx.doi.org/10.1016/0016-7037(91)90023-X

Bennett P.C., Melcer M.E., Siegel D.I. \& Hassett J.P., 1988 - The dissolution of quartz in dilute aqueous solutions of organic acids at $25^{\circ} \mathrm{C}$. Geochimica et Cosmochimica Acta, 52: 1521-1530. http://dx.doi.org/10.1016/0016-7037(88)90222-0

Boston P.J., Spilde M.N., Northup D.E., Melim L.A., Soroka D.S., Kleina L.G., Lavoie K.H., Hose L.D., Mallory L.M., Dahm C.N., Crossey L.J. \& Schelble R.T., 2004 - Cave biosignature suites: microbes, minerals, and Mars. Astrobiology. 1 (1): 25-55. http://dx.doi.org/10.1089/153110701750137413

Daza Brunet R. \& Bustillo-Revuelta M.Á., 2014 Exceptional silica speleothems in a volcanic cave: a unique example of silicification and sub-aquatic opaline stromatolite formation (Terceira, Azores). Sedimentology, 61: 2113-2135. http://dx.doi.org/10.1111/sed.12130

Dreybrodt W., 1980 - Deposition of calcite from thin films of natural calcareous solutions and the growth of speleothems. Chemical Geology, 29 (1-4): 89-105. http://dx.doi.org/10.1016/0009-2541(80)90007-8

Dreybrodt W., 1981 - The kinetics of calcite precipitation from thin films of calcareous solutions and the growth of speleothems: revisited. Chemical Geology, 32 (1-4): 237-245.

http://dx.doi.org/10.1016/0009-2541(81)90146-7

Espinasa-Pereña R., 2006 - Lava Tubes of the Suchiooc volcano, Mexico. Association for Mexican Cave Studies, Bulletin 6, Austin, Texas, USA, 80 p.

Forti P., 2005 - Genetic processes of cave minerals in volcanic environments: an overview. Journal of Cave and Karst Studies, 67 (1): 3-13.

Forti P., Galli E. \& Rossi A., 2003 - Minerogenesis of volcanic caves of Kenya. International Journal of Speleology, 32 (1-4): 3-18.

http://dx.doi.org/10.5038/1827-806X.32.1.1 
Greeley R. \& Hyde J.H., 1972 - Lava tubes of the Cave Basalt, Mount St. Helens, Washington. Bulletin of the Geological Society of America, 83 (8): 2397-2418. http://dx.doi.org/10.1130/0016-7606(1972)83[2397 :LTOTCB]2.0.CO;2

Halliday W.R., 1994 - Extrusion of lava branched forms and dripstone. Hawaii Grotto News, 3 (2): 10.

Hathaway J., Garcia M., Balasch M., Spilde M., Stone F., Dapkevicius M.L.N.E, Amorim I.R., Gabriel R., Borges P.A.V. \& Northup D.E., 2014 - Comparison of bacterial diversity in Azorean and Hawaiian lava cave microbial mats. Geomicrobiology Journal, 31: 205-220. http://dx.doi.org/10.1080/01490451.2013.777491

Herdianita N.R., Browne, P.R.L. \& Rodgers, K.A. 2000 - Mineralogical and textural changes accompanying ageing of silica sinter. Mineralium Deposita, 35: 48-62. http://dx.doi.org/10.1007/s001260050005

Hill C.A. \& Forti P., 1995 - The classification of cave minerals and speleothems. International Journal of Speleology, 24: 77-82.

http:/ /dx.doi.org/10.5038/1827-806X.24.1.5

Kempe S., 2011 - Morphology of speleothems in primary (lava) and secondary caves. In: Frumkin A. (Ed.), Treatise in Geomorphology 6, Karst Geomorphology, p. 267-285.

Kimura T. \& Koga N., 2011 - Monohydrocalcite in comparison with hydrated amorphous calcium carbonate: precipitation condition and thermal behavior. Crystal Growth \& Design, 11: 3877-3884.

http://dx.doi.org/10.1021/cg200412h

Konhauser K.O. \& Ferris F.G., 1996 - Diversity of iron and silica precipitation by microbial mats in hydrothermal waters, Iceland: implications for Precambrian iron formations. Geology, 24: 323-326.

http://dx.doi.org/10.1130/0091-7613(1996)024 $<0323$ :DOIASP $>2.3 . \mathrm{CO} ; 2$

Konhauser K.O., Phoenix V.R., Bottrell S.H. \& Adams D.G., 2001 - Microbial-silica interactions in Icelandic hot spring sinter: possible analogues for some Precambrian siliceous stromatolites. Sedimentology, 48: 415-433.

http://dx.doi.org/10.1046/j.1365-3091.2001.00372.x

Last F.M., Last W.M. \& Halden N.M., 2010 - Carbonate microbialites and hardgrounds from Manito Lake, an alkaline, hypersaline lake in the northern Great Plains of Canada. Sedimentary Geology, 225: 34-49. http://dx.doi.org/10.1016/j.sedgeo.2010.01.006

Léveillé R.J. \& Datta S., 2010 - Lava tubes and basaltic caves as astrobiological targets on Earth and Mars: a review. Planet Space Science, 58: 592-598.

http://dx.doi.org/10.1016/j.pss.2009.06.004

Léveillé R.J., Fyfe W.S. \& Longstaffe F.J., 2000 Geomicrobiology of carbonate-silicate microbialites from Hawaiian basaltic sea caves. Chemical Geology, 169: 339-355.

http://dx.doi.org/10.1016/S0009-2541(00)00213-8

Lundberg J., Brewer-Carias C. \& McFarlane D.A., 2010 - Preliminary results from U-Th dating of glacialinterglacial deposition cycles in a silica speleothem from Venezuela. Quaternary Research, 74: 113-120. http://dx.doi.org/10.1016/j.yqres.2010.03.005

Ludwig K.R. \& Paces J.B., 2002 - Uranium-series dating of pedogenic silica and carbonate, Crater Flat, Nevada. Geochimica et Cosmochimica Acta, 66: 487-506. http://dx.doi.org/10.1016/S0016-7037(01)00786-4

Lynne B.Y., Campbell K.A., Moore J. \& Browne P.R.L., 2008 - Origin and evolution of the Steamboat Springs siliceous sinter deposit, Nevada, USA. Sedimentary Geology, 210: 111-131.

http://dx.doi.org/10.1016/j.sedgeo.2008.07.006
Miller A.Z., Hernández-Mariné M., Jurado V., Dionísio A., Barquinha P., Fortunato E., Afonso M.J., Chaminé H.I. \& Saiz-Jimenez C., 2012 - Enigmatic reticulated filaments in subsurface granite. Environmental Microbiology, 4: 596-603.

http://dx.doi.org/10.1111/j.1758-2229.2012.00375.x

Miller A.Z., Pereira M.F.C., CalaforraJ.M., Forti P., Dionísio A. \& Saiz-Jimenez C., 2014 -Siliceous speleothems and associated microbe-mineral interactions from Ana Heva Lava Tube in Easter Island (Chile). Geomicrobiology Journal, 31 (3): 236-245.

http://dx.doi.org/10.1080/01490451.2013.827762

Munemoto T. \& Fukushi K., 2008 - Transformation kinetics of monohydrocalcite to aragonite in aqueous solutions. Journal of Mineralogical and Petrological Sciences, 103: 345-349.

http://dx.doi.org/10.2465/jmps.080619

Neumann M. \& Epple M., 2007 - Monohydrocalcite and its relationship to hydrated amorphous calcium carbonate in biominerals. European Journal of Inorganic Chemistry, 14: 1953-1957.

http://dx.doi.org/10.1002/ejic.200601033

Northup D.E., Melim L.A., Spilde M.N., Hathaway J.J.M., García M.G., Moya M., Stone F.D., Boston P.J., Dapkevicius M.L.N.E. \& Riquelme C., 2011 - Lava cave microbial communities within mats and secondary mineral deposits: Implications for life detection on other planets. Astrobiology, 11 (7): 601-618.

http://dx.doi.org/10.1089/ast.2010.0562

Onac B.P. \& Forti P., 2011 - Minerogenetic mechanisms occurring in the cave environment: an overview. International Journal of Speleology, 40: 79-98. http://dx.doi.org/10.5038/1827-806X.40.2.1

Onac B.P., Sumrall J., Tamăş T., Povară I., Kearns J., Dârmiceanu V., Vereş D. \& Lascu C., 2009 - The relationship between cave minerals and H2S-rich thermal waters along the Cerna Valley (SW Romania). Acta Carsologica, 38 (1): 67-79.

http://dx.doi.org/10.3986/ac.v38i1.135

Orange F., Lalonde S.V. \& Konhauser K.O., 2013 Experimental simulation of evaporation-driven silica sinter formation and microbial silicification in hot spring systems. Astrobiology, 13 (2): 163-176.

http://dx.doi.org/10.1089/ast.2012.0887

Polyak V.J., Jacka A.D. \& Güven N., 1994 Monohydrocalcite in speleothems from caves in the Guadalupe Mountains New Mexico. National Speleological Society Bulletin, 56 (1): 27-31.

Rasmussen B., Blake T.S., Fletcher I.R. \& Kilburn M.R., 2009 - Evidence for microbial life in synsedimentary cavities from $2.75 \mathrm{Ga}$ terrestrial environments. Geology, 37: 423-426.

http://dx.doi.org/10.1130/G25300A.1

Robin C.R., Deurlington A., Buck B.J. \& Brock-Hon A.L., 2015 - Micromorphology and formation of pedogenic ooids in calcic soils and petrocalcic horizons. Geoderma, 251-252: 10-23.

http://dx.doi.org/10.1016/j.geoderma.2015.03.009

Rodriguez-Blanco J.D., Shaw S., Bots P., RoncalHerrero T. \& Benning L.G., 2014 - The role of $\mathrm{Mg}$ in the crystallization of monohydrocalcite. Geochimica et Cosmochimica Acta, 127: 204-220.

http://dx.doi.org/10.1016/j.gca.2013.11.034

Sallstedt T., Ivarsson M., Lundberg J.E.K., Sjöberg R. \& Vidal-Romaní J.R., 2014 - Speleothem formation and microbial colonization in a granite/dolerite cave Northern Sweden. International Journal of Speleology, 43 (3): 305-313.

http://dx.doi.org/10.5038/1827-806X.43.3.7 
Siebe C., Rodriguez-Laura V., Schaaf P. \& Abrahms M., 2004 - Radiocarbon ages of Holocene Pelado, Guespalapa, and Chichinautzin scoria cones, south of Mexico-City: Implications for archaeology and future hazards. Bulletin of Volcanology, 66: 203-225. http://dx.doi.org/10.1007/s00445-003-0304-Z

Toporski J.K.W., Steele A., Westall F., Thomas-Keprta K.L. \& McKay D.S., 2002 - The simulated silicification of bacteria - New clues to the modes and timing of bacterial preservation and implications for the search for extraterrestrial microfossils. Astrobiology, 2: 1-26. http://dx.doi.org/10.1089/153110702753621312

Urbani F., 1976 - Opalo, calcedonia y calcita en la Cueva del Cerro Autano (Am 11), Territorio Federal Amazonas, Venezuela. Boletín de la Sociedad Venezolana de Espeleología, 7: 129-145.

Vidal-Romaní J.R., González L., Vaqueiro M. \& Sanjurjo J., 2015 - Bioweathering related to groundwater circulation in cavities of magmatic rock massifs. Environmental Earth Sciences, 73: 2997-3010.

http://dx.doi.org/10.1007/s12665-014-3743-2

Vidal-Romaní J.R., Sanjurjo J.J., Vaqueiro M. \& Fernández- Mosquera D., 2010 - Speleothem development and biological activity in granite cavities. Geomorphologie: relief, processes, environment, 4: 337-346.
Vidal-Romaní J.R., Twidale C.R., Bourne J. \& Campbell E.M., 1998 - Speleothems and constructive forms in granitoids. In: Ortíz A.G. \& Franch, F.S. (Eds.), Recent researches in Spain Geomorphology. Actas Reunión de Geomorfología (Granada) 1 $1^{\mathrm{a}}$ edición: p. 777-782. (in Spanish).

Webb J.A. \& Finlayson B.L., 1984 - Allophane and opal speleothems from granite caves in south-east Queensland. Australian Journal of Earth Sciences, 31: 341-349. http:/ /dx.doi.org/10.1080/14400958408527935

Willems L., Compère P.H., Hatert F., Pouclet A., Vicat J.P. \& Boulvain F., 2002 - Karst in granitic rocks, South Cameroon: cave genesis and silica and taranakite speleothems. Terra Nova, 14: 355-362.

http://dx.doi.org/10.1046/j.1365-3121.2002.00429.x

Woo K.S., Choi D.W. \& Lee K.C., 2008 - Silicification of cave corals from some lava tube caves in the Jeju Island, Korea: implications for speleogenesis and a proxy for paleoenvironmental change during the Late Quaternary. Quaternary International, 176-177: 82-95.

http://dx.doi.org/10.1016/j.quaint.2007.05.008

Wray R.A.L., 1999 - Opal and chalcedony speleothems on quartz sandstones in the Sydney region, southeastern Australia. Australian Journal of Earth Sciences, 46: 623-632.

http://dx.doi.org/10.1046/j.1440-0952.1999.00732.x 